\title{
Applications of Living Systems Theory to Life in Space ${ }^{*}$
}

\author{
James Grier Miller
}

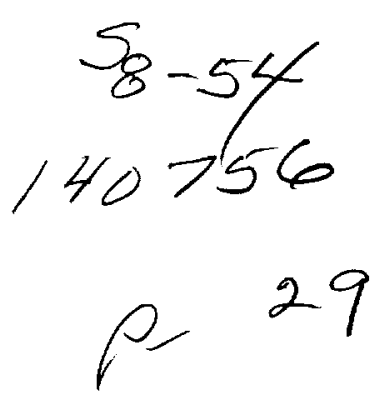

\section{Introduction}

Earth, so far as we know, is the only planet in our solar system on which living systems have ever existed. Since Earth's primeval atmosphere lacked free oxygen and therefore had no ozone layer to protect primitive cells and organisms from the Sun's killing radiation, life evolved in the sea for the first two billion years. The biological activity of primitive algae is considered a major factor in creating our oxygen atmosphere, making it possible to colonize land.

Now the human species is contemplating a second great migration, this time into space. Human settlements, first on space stations in orbit and then on bases on the Moon, Mars, and other planetary bodies, are in the planning stage.

Planning for nonterrestrial living requires a reorientation of the longrange strategic purposes and shortrange tactical goals and objectives of contemporary space programs. The primary focus must be on the human beings who are to inhabit the projected settlements. This implies a shift in thinking by space scientists and administrators so that a satisfactory quality of human life becomes as important as safety during space travel and residence. Planners are challenged not only to provide transportation, energy, food, and habitats but also to develop social and ecological systems that enhance human life.

Making people the dominant consideration does not diminish the need to attend to technologies for taking spacefarers to their new homes and providing an infrastructure to sustain and support them in what will almost certainly be a harsh and stressful setting (Connors, Harrison, and Akins 1985).

As clear a vision as possible of human organizations and settlements in space and on nonterrestrial bodies in the 21st century should be gained now. A beginning was made by the National Commission on Space (1986) in depicting the human future on the space frontier. Behavioral scientists, particularly those with a general systems orientation, can contribute uniquely to this process. They can do research to improve strategic and programmatic planning focused on human needs and behavior. The results should prove to be the drivers of the mechanical, physical, and biological engineering required to create the space infrastructure.

*Presented at the NASA-NSF conference The Human Experience in Antarctica: Applications to Life in Space, held in Sunnyale, CA, August 17, 1987. 


\section{Spacelab 1}

As technicians examine the Spacelab module, a physician examines a prospective occupant. As we contemplate long journeys to other planets and lengthy stays in space, we must plan not only for the safe transportation and life support of spacefarers but also for their comfort and well-being. The high motivation that has characterized astronauts and cosmonauts in space flights so far cannot be expected to endure avoidable difficulties throughout long missions.

Artist: Charles Schmidt (NASA Art Program Collection)
When we envision nonterrestrial stays of long duration, we must plan for quite different social phenomena than we have seen in space missions up to now. Astronauts have lived on space stations for periods of a few weeks or months at most. The great majority of missions have been relatively brief. Such missions have required the daring and initiative of carefully selected and highly trained astronauts equipped to accomplish limited goals. If people are to remain permanently in settlements far from Earth, however, they cannot endure the inconvenient, uncomfortable, and difficult working and living conditions that have been the lot of the highly trained and motivated professionals who have gone into space over the past 30 years. Months and years in a space environment are an entirely different matter. Motivation diminishes over time and longcontinued discomforts are hard to bear.

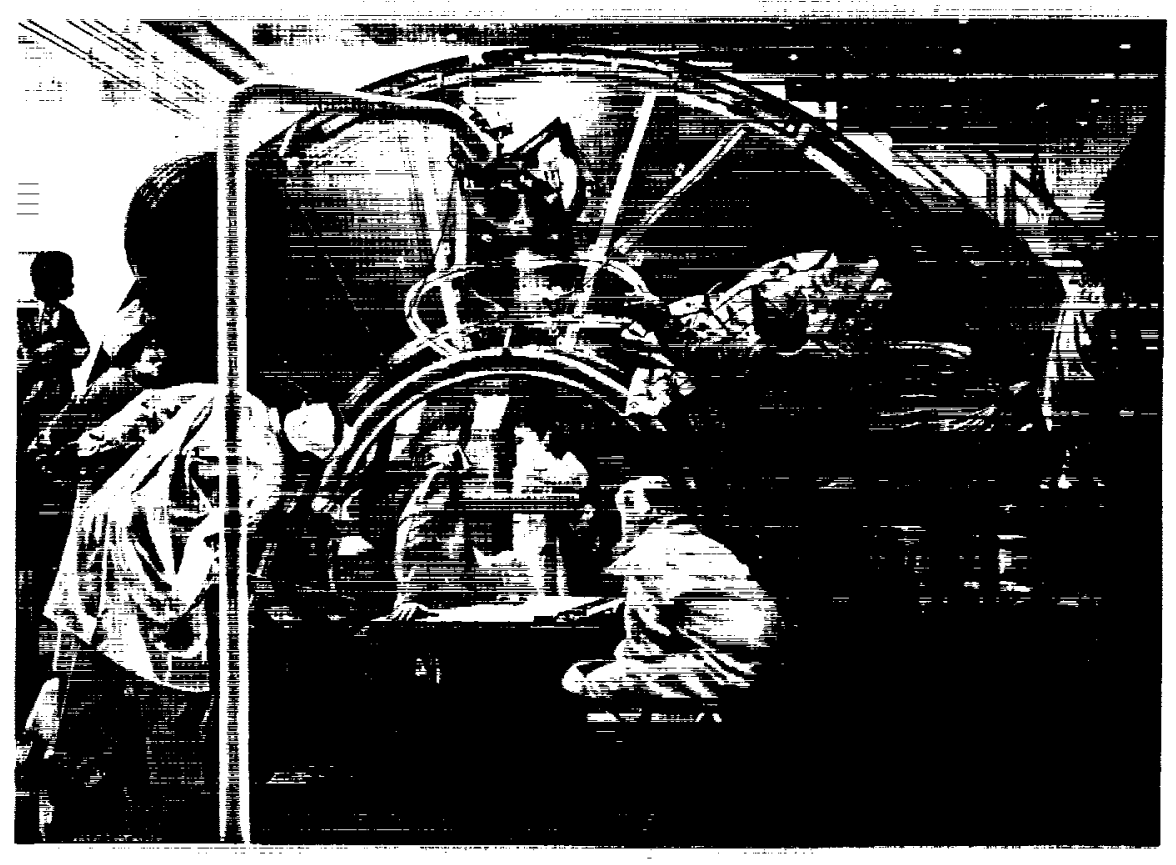


If men, women, and perhaps even children live together in nonterrestrial locations which, even with excellent communications to Earth, are inevitably isolating, their behavior will undoubtedly be different from any that has so far been observed in space. A new space culture may well arise (see Harris's paper on space culture in this volume). This is particularly likely in an international program that includes people from different nations and diverse cultures. It is not too early to begin systematically to try to understand what such settlements will be like in order to plan wisely for them.

No place on Earth closely resembles the conditions in space, on the Moon, or on other planetary bodies. The harsh environmental stresses and the isolation that must be faced by people who winter over in Antarctica, however, are similar in many ways. If the logistical problems of doing research there and the attendant costs can be coped with, perhaps Antarctica is the best place within the Earth's gravity field to analyze the problems of life in space and even to put a space station simulator or to model a lunar outpost. Also it is a good place to develop plans for continuous monitoring of human behavior under rigorous conditions, by procedures such as those based on living systems theory, which is outlined below. If that kind of Antarctic research is infeasible or unduly costly, we can consider doing space station research at other locations, such as the Space Biospheres at Oracle, Arizona, or on space station simulators at Marshall Space Flight Center in Huntsville, Alabama; at McDonnell Douglas Corporation in Huntington Beach, California; or at Ames Research Center at Moffett Field, California. 
Researcher notes condition of insectgrowing area at Biosphere II

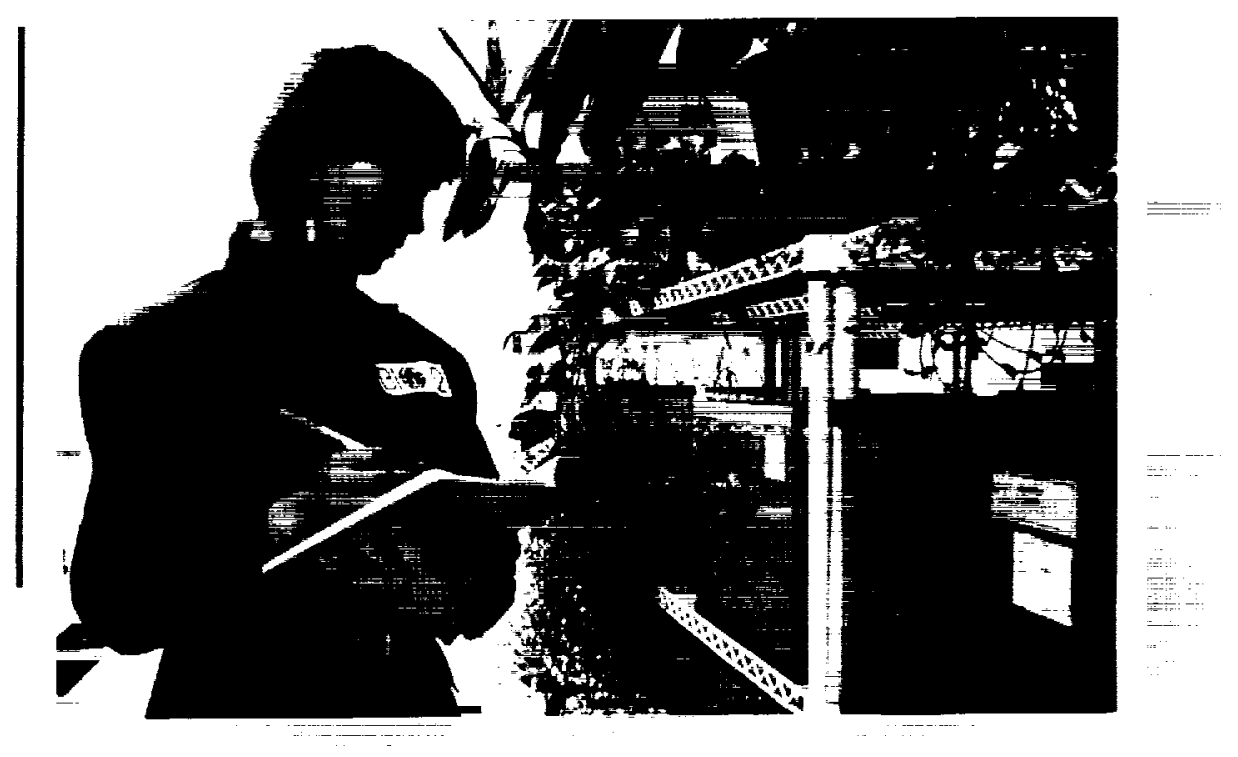

\section{Biosphere II Test Module}

On November 2, 1989, botanist Linda Leigh stepped inside an airlock and entered an ecosystem separate from the biosphere of the Earth. For the next 21 days, the air she breathed, the water she drank, and the food she ate were generated by the ecosystem within the 17000 -cubic-foot airtight glass and steel Test Module of Space Biospheres Ventures in Oracle, Arizona. Leigh harvested fruits, vegetables, herbs, and fish grown in the module and prepared them in the module's human habitat section, which includes an efficiency kitchen, a bathroom with a shower, a bed. and a study area with a desk. She communicated with colleagues and observed air and water quality data, by computer monitor. In this, as in the previous two tests, all environmental quality indicators remained well within safety limits and the human inhabitant remained in excellent health and spirits. James Grier Miller suggests the application of measures based on living systems theory to human behavior in such a simulation of life on a space station.

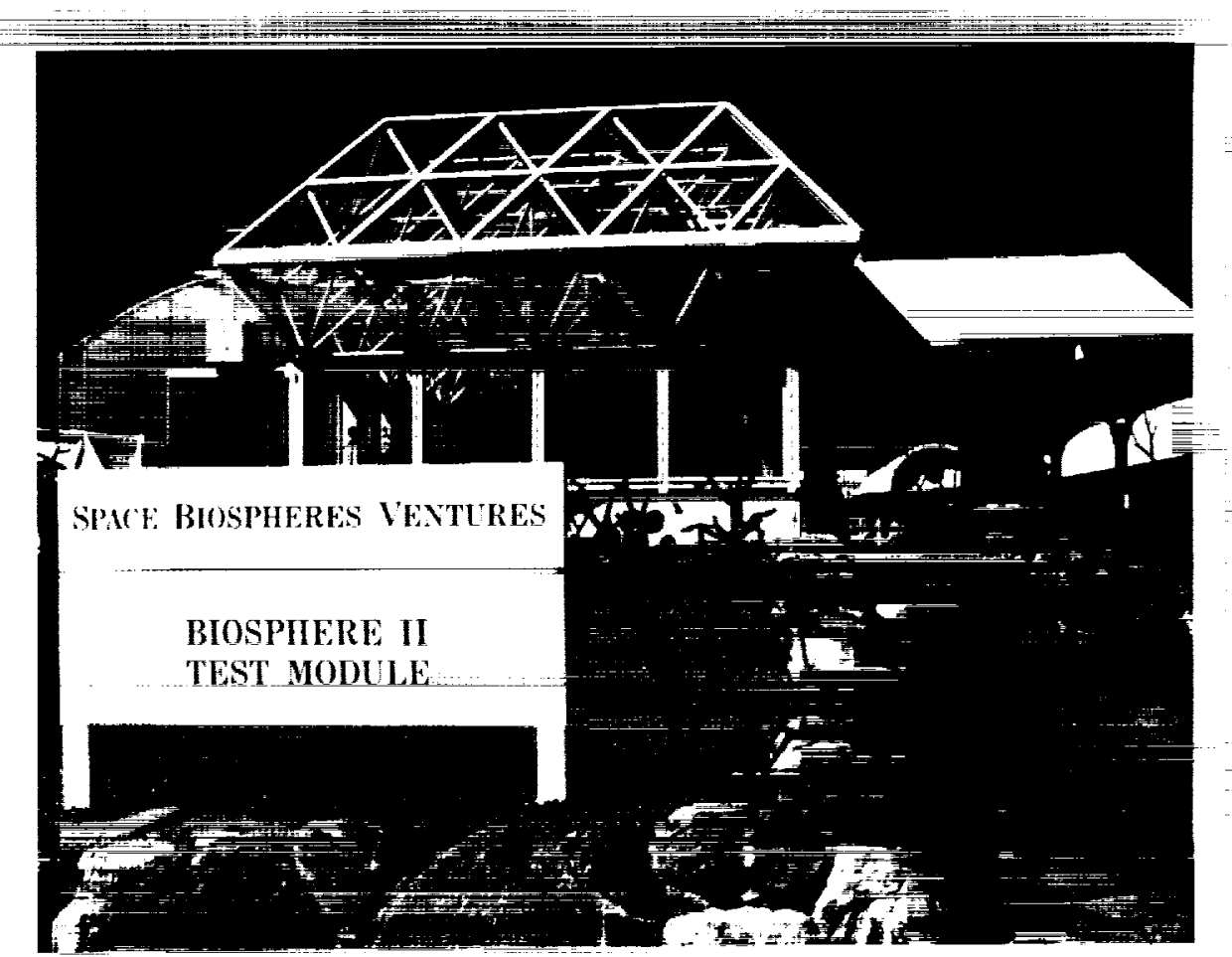




\section{ORIGINAL FAS \\ BLACK AND WHITE PHOTOGRAPH}

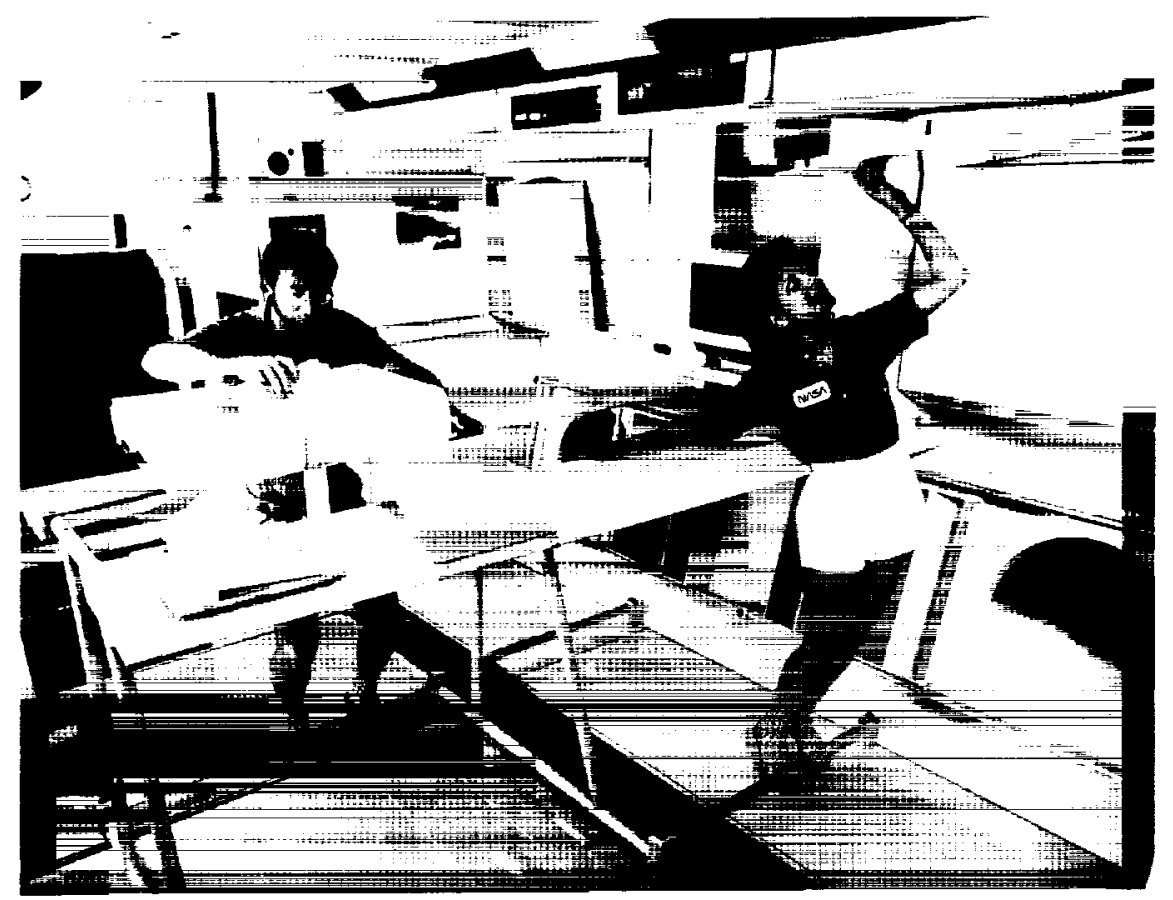

\section{Synopsis of Living Systems Theory}

Living systems theory (LST) provides one possible basis for such research. This is an integrated conceptual approach to the study of biological and social living systems, the technologies associated with them, and the ecological systems of which they are all parts. It offers a method of analyzing systems - living systems process analysis - which has been used in basic and applied research on a variety of different kinds of systems.
Since 1984 my colleagues and I have been examining how LST can contribute to the effectiveness of space planning and management. At the NASA summer study in LaJolla, we focused on strategic planning for a lunar base. Since then a team of behavioral and other scientists has explored ways in which a living systems analysis could be employed by NASA to enhance the livability of the Space Shuttle and eventually of the space station.

The LST approach to research and theoretical writing differs significantly from that commonly

\section{Space Station Trainer}

This accurate physical mockup of a space station module is used to train prospective crewmembers in the use of equipment. The Johnson Space Center also has simulators, which, although they do not look from the outside as the actual hardware will look, do give crewmembers the feeling of being in space. It is not possible to make a trainer/simulator that both looks and feels like the real thing. NASA planners also look at analog situations, like the isolated environment at the South Pole, to study how people function under such rigorous conditions. 
followed in empirical science. One reason for this difference is that LST was developed by an interdisciplinary group of scientists rather than representatives of one discipline. Many members of the group were senior professors with national and international recognition in their own specialties. All members had advanced training in at least one discipline. But they agreed on the importance of achieving unity in science, working toward the goal of its ultimate integration by developing general theories. Research concerned with living systems is designed with this goal in mind. It focuses on the following concerns.

\section{Compartmentalization of Science}

Modern science suffers from structural problems that have their roots in conceptual issues. The organization of universities by departments, and the structure of science generally, emphasizes the separate disciplines. The rewards of academic life are given for becoming expert in a specialty or subspecialty. It is important, however, that, although the major work of science must be done by specialists, they should all realize that they are contributing to a mosaic and that their work fits, like a piece of a jigsaw puzzle, into an overall picture.
In the real world of daily affairs, whether one is dealing with computers and information processing or with housing, finance, legislation, or industrial production, the problems are always interdisciplinary. The problems that face space enterprises are also interdisciplinary. Each major project needs the skills of engineers, lawyers, economists, computer scientists, biologists, and social scientists in different combinations.

\section{Inductive General Theory}

There are two major stages in the scientific process: first the inductive stage, and, second, the deductive stage. The inductive stage is logically prior. Scientists begin the first stage by observing some class of phenomena and identifying certain similarities among these phenomena. Then they consider alternative explanations for these similarities and generate hypotheses to determine which explanation is correct.

A goal of science that has been recognized for centuries is the development of both special theories of limited scope and general theories that unify or integrate special theories and cover broader spheres of knowledge. It is usually necessary to start with 
special theories that deal with a limited set of phenomena. Middlerange theories concerned with a greater number of phenomena come later. Ultimately a body of research based on these leads to general theories that include a major segment of the total subject matter of a field or of several fields.

The desirability and usefulness of general theory is more widely acknowledged in some disciplines, like mathematics and physics, than in others. Unfortunately many students of science and even senior scientists have not been taught about this goal and are unaware of it. Of course scientists, under the principles of the First Amendment and of academic freedom, may generate their hypotheses any way they please. Then they can test or evaluate them by collecting data and either confirm or disprove them. The findings resulting from such a procedure, however, may not have any discoverable relationship to the findings of any other research in the same field.

Voluntary scientific self-discipline in the mature sciences leads researchers to prefer to carry out studies which test hypotheses that distinguish critically between alternative special theories, middle-range theories, and ultimately general theories. The goal of research on LST is to collect data to make deductive tests of hypotheses derived from inductive, integrative theory.

\section{Common Dimensions}

If scientists or engineers from different fields are to work together, it is desirable that the dimensions and measurements they use be compatible. Experimenters in physical and biological sciences ordinarily make their measurements using dimensions identical to those used by other scientists in those fields, or other units that have known transformations to them.

It should eventually be possible to write transformation equations to reduce dimensions of any of the disciplines of physical, biological, or social science into common dimensions that are compatible with the meter-kilogram-second system of measurement so that specialists in different fields can communicate precisely. Investigators studying LST attempt to use such dimensions whenever it is possible.

If some phenomena of living systems cannot be measured along such dimensions, one or more others may have to be used. If this is done, however, an explicit statement should always be made that those particular dimensions 
are incommensurable with the established dimensions of natural science. Furthermore, resolute efforts should be made to discover transformation equations that relate them to the established dimensions. Our experience indicates that in many cases this can be done. The use of transformation equations is advocated rather than an attempt to go directly to some system of common dimensions because people in different disciplines often feel that the measures to which they are accustomed are preferable in their own fields. Transformation equations are a reasonable first step to common dimensions.

Comparable dimensions for living and nonliving systems are increasingly useful as matterenergy and information processing technologies become more sophisticated and are more widely employed throughout the world. The design of person/machine interfaces, for example, is more precise and efficient when both sides are measured comparably. Engineers and behavioral scientists are able to cooperate in joint projects much more effectively than they ordinarily have in the past. Such cooperation greatly facilitates space science. Such comparability of dimensions is a main theme of the program projected in this proposal.

\section{Coexistence of Structure and Process}

It is important not to separate functional (that is, process) science from structural science. Psychology and physiology are process sciences at the level of the organism, and sociology and political science are process sciences at the level of the society. Gross anatomy and neuroanatomy are structural sciences at the level of the organism, and physical geography is a structural science at the level of the society.

A psychologist or neurophysiologist, however, is inevitably limited if she or he cannot identify the anatomical structure that mediates an observed process, and an anatomist can have only a partial understanding of a structure without comprehending its function. Consequently, whenever a process has been identified but the structure that carries it out is not known, it should be an insistent goal of science to identify the structure. The opposite is also true: It should be an insistent goal of science to identify the process or processes that a structure carries out. Often this is disregarded because it is not thought to be urgent. The main reason for this appears to be that, in the academic world, process or functional sciences are administratively separate from, 
and in poor communication with, their relevant structural sciences (e.g., gross anatomy at the level of the organism or physical geography at the level of the society).

\section{Biosocial Evolution}

Living systems are open systems that take from the environment substances of lower entropy and higher information content (food, energy, information) than they put back into the environment (waste, heat, noise). This thermodynamically improbable increase of internal information (negative entropy), which does not occur in nonliving systems, makes it possible for them to grow, do work, make products, and carry on other life functions.

On the basis of a mass of supporting scientific evidence, LST asserts that over the last approximately 3.8 billion years a continuous biosocial evolution has occurred, in the overall direction of increased complexity. It has so far resulted in eight levels of living systems: cells, organs, organisms, groups, organizations, communities, societies, and supranational systems. This evolution came about by a process of fray-out (see fig. 1) in which the larger, higher-level systems evolved with more (and more complex) components in each subsystem than those below them in the hierarchy of living systems. Fray-out can be likened to the unraveling of a ship's cable. The cable is a single unit but it can separate into the several ropes that compose it. These can unravel further into finer strands, strings, and threads.

Systems at each succeeding level are composed principally of systems at the level below. Cells have nonliving molecular components, organs are composed of cells, organisms of organs, groups are composed of organisms, and so on. Systems at higher levels are suprasystems of their component, lower-level systems, which are organized into subsystems, each of which performs one of the activities essential to all living systems.

Our identification of these subsystems was under way by 1955. By 1965 we had identified 19 of them. A 20th, the timer, was identified only recently (Miller 1990). It is interesting that a group of researchers at Lockheed Corporation in 1985, apparently without any underlying conceptual theory or any knowledge of our previous work, identified a set of elements and subelements of the living and nonliving aspects of a space station with significant similarities to our subsystems. They were not wholly comparable, however. One incompatibility is that the Lockheed researchers listed as elements or subelements not only what we call "subsystems" but also what we call "levels" and "flows." 


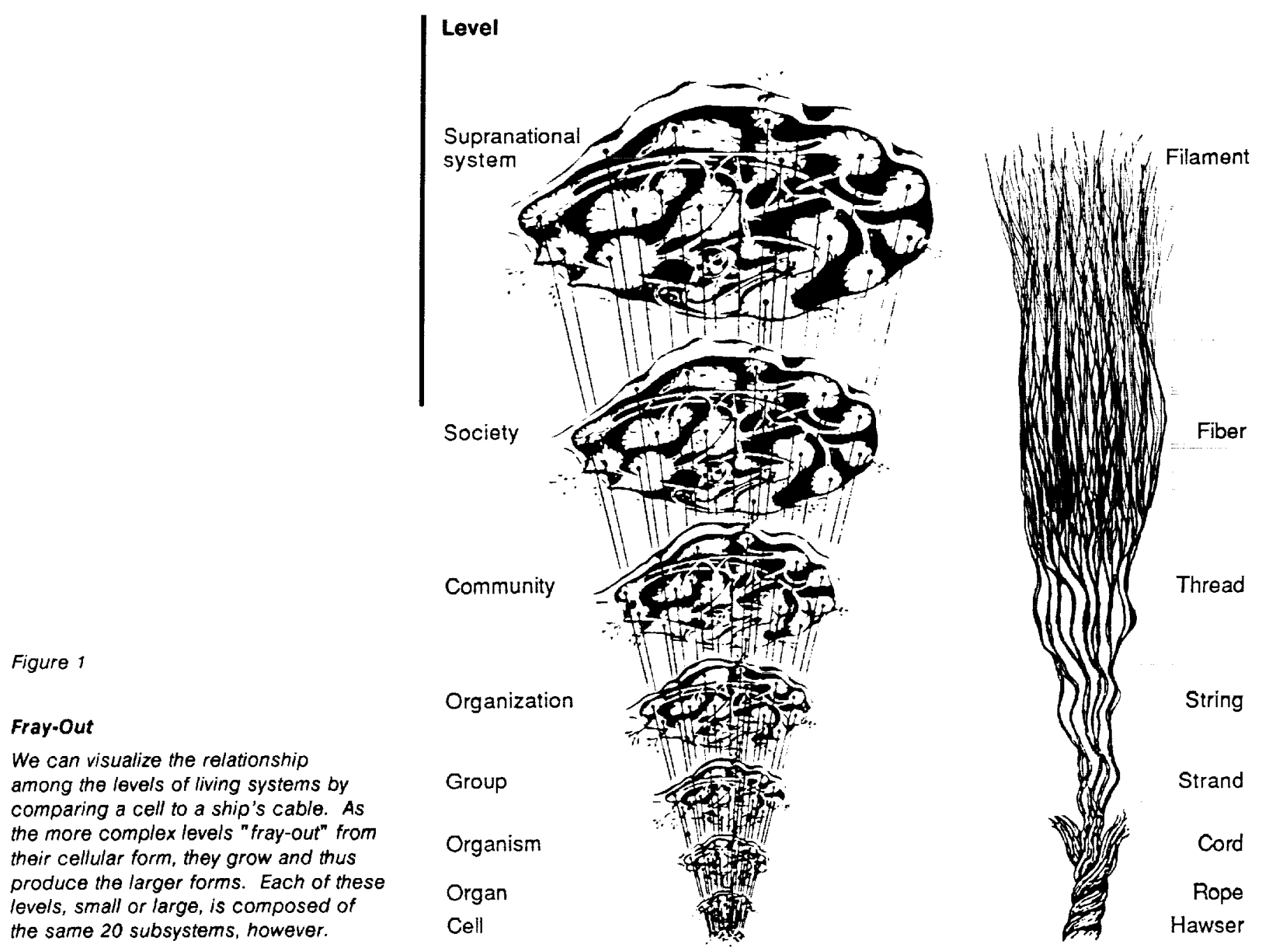




\section{Emergents}

The fact that systems at each level have systems at the level next below as their principal components doesn't mean that it is possible to understand any system as just an accumulation of lower-level systems. A cell cannot be described by summing the chemical properties of the molecules that compose it, nor can an organism be described by even a detailed account of the structure and processes of its organs. LST gives no support to reductionism. At each higher level of living systems there are important similarities to the lower levels, but there are also differences. Higherlevel systems have emergent structures and processes that are not present at lower levels.

Emergents are novel processes, made possible because higher-level systems have a greater number of components with more complicated relationships among them. It is this increased complexity that makes the whole system greater than the simple sum of its parts, and gives it more capability. Higher-level systems are larger, on average, and more complex than those below them in the hierarchy of living systems. They can adapt to a greater range of environmental variation, withstand more stress, and exploit environments not available to less complex systems.

\section{The Subsystems of Living Systems}

Because of the evolutionary relationship among them, all living systems have similar requirements for matter and energy, without which they cannot survive. They must secure food, fuel, or raw materials. They must process their inputs in various ways to maintain their structure, reproduce, make products, and carry out other essential activities. The metabolism of matter and energy is the energetics of living systems.

Input, processing, and output of information is also essential in living systems. This is the "metabolism" of information.

LST identifies 20 essential processes which, together with one or more components, constitute the 20 subsystems of living systems (see table 1). With the exception of the 2 subsystems of the learning process, which seem to have evolved with animal organisms, all 20 processes appear to be present at each of the eight levels, although they may not be present in all types of systems at a given level. Bacteria, which are cells, for example, have no motor subsystems but many other types of cells have motor components and can move about in the 
environment or move parts of the environment with relation to them. Similarly, some groups and organizations process little or no matter-energy. Some systems clearly have components for certain processes but these components have not been identified. This is largely true for organism associating. Even the simplest animals have some form of learning but the components are not certainly known.

\section{TABLE 1. The Subsystems of Living Systems}

Subsystems which process both matter-energy and information

1. Reproducer, the subsystem which carries out the instructions in the genetic information or charter of a system and mobilizes matter, energy, and information to produce one or more similar systems.

2. Boundary, the subsystem at the perimeter of a system that holds together the components which make up the system, protects them from environmental stresses, and excludes or permits entry to various sorts of matter-energy and information.

Subsystems which process matter-energy

3. Ingestor, the subsystem which brings matter-energy across the system boundary from the environment

4. Distributor, the subsystem which carries inputs from outside the system or outputs from its subsystems around the system to each component.

5. Converter the subsystem which changes certain inputs to the system into forms more useful for the special processes of that particular system.

6. Producer, the subsystem which forms stable associations that endure for significant periods among matter-energy inputs to the system or outputs from its converter, the materials synthesized being for growth, damage repair, or replacement of components of the system, or for providing energy for moving or constituting the system's outputs of products or information markers to its suprasystem.

7. Matter-energy storage, the subsystem which places matter or energy at some location in the system, retains it over time, and retrieves it.

8. Extruder, the subsystem which transmits matter-energy out of the system in the forms of products or wastes.

9. Motor, the subsystem which moves the system or parts of it in relation to part or all of its environment or moves components of its environment in relation to each other

10. Supporter, the subsystem which maintains the proper spatial relationships among components of the system, so that they can interact without weighting each other down or crowding each other. which process information

11. Input transducer, the sensory subsystem which brings markers bearing information into the system, changing them to other matter-energy lorms suitable for transmission within it.

12. Internal transducer, the sensory subsystem which receives, from subsystems or components within the system, markers bearing information about significant alterations in those subsystems or components, changing them to other matter-energy forms of a sort which can be transmitted within it.

13. Channel and net, the subsystem composed of a single route in physical space or multiple interconnected routes over which markers bearing information are transmitted to all parts of the system.

14. Timer, the subsystem which transmits to the decider information about timerelated states of the environment or of components of the system. This information signals the decider of the system or deciders of subsystems to start stop, alter the rate, or advance or delay the phase of one or more of the system's processes, thus coordinating them in time.

15. Decoder, the subsystem which alters the code of information input to it through the input transducer or internal transducer into a "private" code that can be used internally by the system.

16. Associator, the subsystem which carries out the first stage of the learning process, forming enduring associations among items of information in the system.

17. Memory, the subsystem which carries out the second stage of the learning process storing information in the system for different periods of time, and then retrieving it.

18. Decider, the executive subsystem which receives information inputs from all other subsystems and transmits to them outputs for guidance, coordination. and control of the system.

19. Encoder. the subsystem which alters the code of information input to it from other information processing subsystems, from a "private" code used internally by the system into a "public" code which can be interpreted by other systems in its environment.

20. Output transducer. the subsystem which puts out markers bearing information from the system, changing markers within the system into other matter-energy forms which can be Iransmitted over channels in the system's environment. 
A set of symbols, shown in figure 2, have been designed to represent the levels, subsystems, and major flows in living systems. They are intended for use in simulations and diagrams and are compatible with the standard symbols of electrical engineering and computer science. They can also be used in graphics and flow charts.

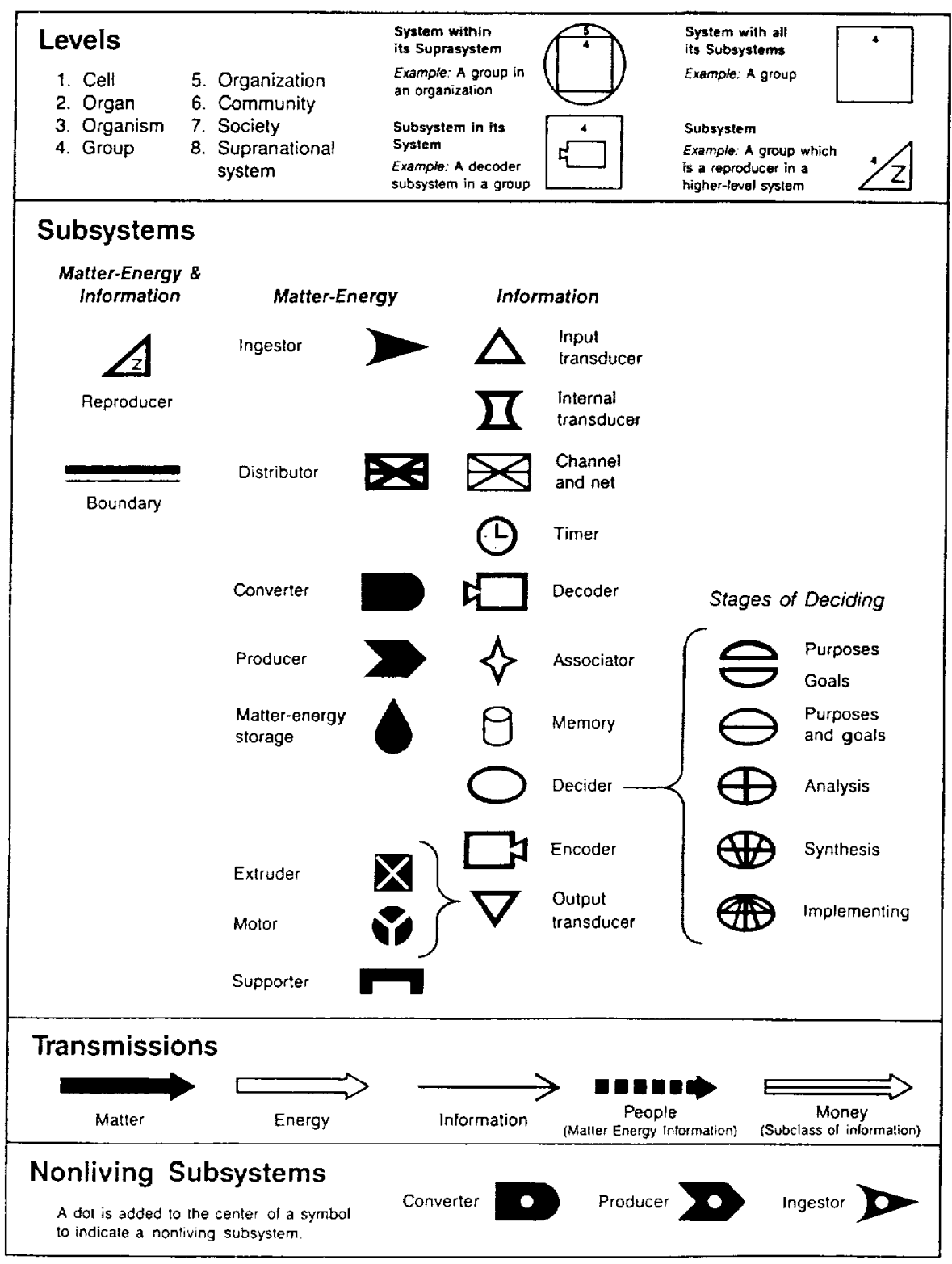

Figure 2

Living Systems Theory Symbols 
If a system lacks components for a given subsystem or part of it, it may disperse the process to a system at the same or another level. Symbiosis and parasitism are examples. The essential part of the associator subsystem in organizations is downwardly dispersed to human brains, since an organization makes associations only when human subcomponents have done so. An organization may, however, have some components, like a training department, that are involved in the process. It is also possible for

TABLE 2. Selected Major Components of Each of the 20 Critical Subsystems at Each of the Eight Levels of Living Systems*

\begin{tabular}{|c|c|c|c|c|c|c|c|c|c|c|}
\hline $\begin{array}{l}\text { Subsystem } \\
\text { Level }\end{array}$ & Reproducer & Eoundary & Ingestar & Distribulor & Converter & Producer & $\begin{array}{l}\text { Matler-energy } \\
\text { slorage }\end{array}$ & Exiruder & Motor & Supporier \\
\hline Cell & $\begin{array}{l}\text { DNA and } \\
\text { RNA } \\
\text { molecules }\end{array}$ & $\begin{array}{l}\text { Matter energy } \\
\text { snd intormation } \\
\text { Ouler membrane }\end{array}$ & $\begin{array}{l}\text { Transport } \\
\text { molecules }\end{array}$ & $\begin{array}{l}\text { Endoplasmic } \\
\text { reticulum }\end{array}$ & $\begin{array}{l}\text { Enzyme fn } \\
\text { mitochandrion }\end{array}$ & $\begin{array}{l}\text { Chloropiasi } \\
\text { in green } \\
\text { plant }\end{array}$ & $\begin{array}{l}\text { Aderosine } \\
\text { tiphosphate }\end{array}$ & $\begin{array}{l}\text { Contractile } \\
\text { vacuoles }\end{array}$ & $\begin{array}{l}\text { Cilla, flagellae. } \\
\text { pseudopodia }\end{array}$ & Cytoskeleton \\
\hline Organ & $\begin{array}{l}\text { Upwardly } \\
\text { dispersed 10 } \\
\text { organism }\end{array}$ & $\begin{array}{l}\text { Matter-energy } \\
\text { and intormation } \\
\text { Capsule or } \\
\text { outer layer }\end{array}$ & Input arlery & $\begin{array}{l}\text { Interceliular } \\
\text { fluid }\end{array}$ & $\begin{array}{l}\text { Parenchymal } \\
\text { cell }\end{array}$ & $\begin{array}{l}\text { Islets of } \\
\text { Langerhans } \\
\text { ol pancreas }\end{array}$ & $\begin{array}{l}\text { Ceniral } \\
\text { lumen of } \\
\text { glands }\end{array}$ & $\begin{array}{l}\text { Output } \\
\text { vein }\end{array}$ & $\begin{array}{l}\text { Smooth muscle, } \\
\text { cardiac muscle }\end{array}$ & Stroma \\
\hline Organism & $\begin{array}{l}\text { Tesies. } \\
\text { ovanies. } \\
\text { ulerus, } \\
\text { genitalia }\end{array}$ & $\begin{array}{l}\text { Matter anergy } \\
\text { and intormstion } \\
\text { Skin ar } \\
\text { other outer } \\
\text { covering } \\
\end{array}$ & $\begin{array}{l}\text { Mouth. } \\
\text { nose, skin. } \\
\text { in some } \\
\text { spectes }\end{array}$ & $\begin{array}{l}\text { Vascular } \\
\text { system ol } \\
\text { higher animals }\end{array}$ & $\begin{array}{l}\text { Upper } \\
\text { gastroinlestinal } \\
\text { leacl }\end{array}$ & $\begin{array}{l}\text { Organs thal } \\
\text { synthesize } \\
\text { malerials for } \\
\text { inetabolism } \\
\text { and repair }\end{array}$ & $\begin{array}{l}\text { Fally } \\
\text { lissues }\end{array}$ & $\begin{array}{l}\text { Sweat } \\
\text { glands ol } \\
\text { animal skin }\end{array}$ & $\begin{array}{l}\text { Sheielal } \\
\text { muscle of } \\
\text { higher animals }\end{array}$ & Skelelon \\
\hline Group & $\begin{array}{l}\text { NASA olficer } \\
\text { who seiects } \\
\text { astronauls lor } \\
\text { crew }\end{array}$ & $\begin{array}{l}\text { Mather anergy. } \\
\text { Inspeciors ol } \\
\text { coverthg of } \\
\text { spacectall } \\
\text { mformalion. } \\
\text { Crew Iadio } \\
\text { operator } \\
\end{array}$ & $\begin{array}{l}\text { Astronauts } \\
\text { who bring } \\
\text { damaged } \\
\text { satellite into } \\
\text { spacecraft }\end{array}$ & $\begin{array}{l}\text { Crewmernber } \\
\text { who disl ibutes } \\
\text { lood }\end{array}$ & $\begin{array}{l}\text { Dispersed lo } \\
\text { maker ol } \\
\text { nackaged } \\
\text { idtions }\end{array}$ & $\begin{array}{l}\text { Ciewmembers } \\
\text { who repalt } \\
\text { damaged } \\
\text { equipment. }\end{array}$ & $\begin{array}{l}\text { Crewmember } \\
\text { who stows } \\
\text { scientific } \\
\text { instruments }\end{array}$ & $\begin{array}{l}\text { Crew that } \\
\text { ejecls satellite } \\
\text { inlo orbit }\end{array}$ & $\begin{array}{l}\text { Downwardly } \\
\text { dispersed to } \\
\text { individuat } \\
\text { members }\end{array}$ & $\begin{array}{l}\text { Crewmembers } \\
\text { who maintain } \\
\text { spacecralt }\end{array}$ \\
\hline Organization & $\begin{array}{l}\text { Disperspdid } \\
\text { upward to } \\
\text { sociely that } \\
\text { creales space } \\
\text { agency }\end{array}$ & $\begin{array}{l}\text { Maller energy. } \\
\text { NASA } \\
\text { inspeciors of } \\
\text { contracled } \\
\text { equipment } \\
\text { Inlarmation } \\
\text { NASA guards } \\
\text { who arrest } \\
\text { intruders }\end{array}$ & $\begin{array}{l}\text { Receiving } \\
\text { department } \\
\text { of NASA } \\
\text { center }\end{array}$ & $\begin{array}{l}\text { Conveyer } \\
\text { beft in } \\
\text { lactory that } \\
\text { makes parls } \\
\text { lor space } \\
\text { habital }\end{array}$ & $\begin{array}{l}\text { Workers who } \\
\text { slamp out } \\
\text { paris lor } \\
\text { spare } \\
\text { vehicle }\end{array}$ & $\begin{array}{l}\text { Doctors who } \\
\text { examine } \\
\text { astronauts }\end{array}$ & $\begin{array}{l}\text { Wotkers } \\
\text { who store } \\
\text { supplies on } \\
\text { space vehicle }\end{array}$ & $\begin{array}{l}\text { Janitors } \\
\text { in NASA } \\
\text { buildings }\end{array}$ & $\begin{array}{l}\text { Driver of } \\
\text { ganily } \\
\text { crane }\end{array}$ & $\begin{array}{l}\text { Janitors in } \\
\text { launch site } \\
\text { buildings }\end{array}$ \\
\hline Communily & $\begin{array}{l}\text { Space agfncy } \\
\text { that osilablishes } \\
\text { space slation }\end{array}$ & $\begin{array}{l}\text { Mothar energy } \\
\text { Dispersed to } \\
\text { builders of } \\
\text { habital } \\
\text { Inlormation } \\
\text { Operators } \\
\text { of downlink } \\
\text { to Earth }\end{array}$ & $\begin{array}{l}\text { Receivers of } \\
\text { maleriats } \\
\text { trom } \\
\text { Shutlia }\end{array}$ & $\begin{array}{l}\text { Food servers } \\
\text { in dining } \\
\text { lacility }\end{array}$ & $\begin{array}{l}\text { Organtzation } \\
\text { lhal mines } \\
\text { Moon }\end{array}$ & $\begin{array}{l}\text { Medical } \\
\text { organization } \\
\text { in space } \\
\text { communily }\end{array}$ & $\begin{array}{l}\text { Woakers } \\
\text { who pul supplies } \\
\text { into slorage } \\
\text { areas }\end{array}$ & $\begin{array}{l}\text { Mine } \\
\text { organizalton } \\
\text { ithal sends } \\
\text { minerals } \\
\text { to Earth }\end{array}$ & $\begin{array}{l}\text { Divers } \\
\text { of Moon } \\
\text { surlace } \\
\text { vehicles }\end{array}$ & $\begin{array}{l}\text { Maintenance } \\
\text { crew of } \\
\text { habital } \\
\text { buildings }\end{array}$ \\
\hline Sociely & $\begin{array}{l}\text { Constilutional } \\
\text { convention that } \\
\text { writes nalional } \\
\text { conslitution }\end{array}$ & $\begin{array}{l}\text { MoHor - energy } \\
\text { Customs service } \\
\text { Informalion. } \\
\text { Security agency }\end{array}$ & $\begin{array}{l}\text { Immigration } \\
\text { service }\end{array}$ & $\begin{array}{l}\text { Operalors of } \\
\text { national } \\
\text { raitrnads }\end{array}$ & $\begin{array}{l}\text { Nuclear } \\
\text { indusiry }\end{array}$ & $\begin{array}{l}\text { All farmers } \\
\text { and laciory } \\
\text { workers al a } \\
\text { counley } \\
\end{array}$ & $\begin{array}{l}\text { Soldiers } \\
\text { in Arrsy } \\
\text { barracks }\end{array}$ & $\begin{array}{l}\text { Export } \\
\text { organizations } \\
\text { of a couniry }\end{array}$ & $\begin{array}{l}\text { Aerospace } \\
\text { indusiry } \\
\text { that buitds } \\
\text { spacecrait }\end{array}$ & $\begin{array}{l}\text { Olficials who } \\
\text { operale national } \\
\text { public buidings } \\
\text { and lands }\end{array}$ \\
\hline $\begin{array}{l}\text { Supranational } \\
\text { systern }\end{array}$ & $\begin{array}{l}\text { Uniled } \\
\text { Nations when } \\
\text { il creales new } \\
\text { suprariational } \\
\text { agency }\end{array}$ & $\begin{array}{l}\text { Matler-anergy. } \\
\text { Troops al } \\
\text { Bertin Wall } \\
\text { h/ormalion } \\
\text { NaIO securily } \\
\text { personnef }\end{array}$ & $\begin{array}{l}\text { Legislalive } \\
\text { body that } \\
\text { admils } \\
\text { nations }\end{array}$ & $\begin{array}{l}\text { Personitel } \\
\text { who operate } \\
\text { supranationat } \\
\text { power grids }\end{array}$ & $\begin{array}{l}\text { EURATOM, } \\
\text { CERN. } \\
\text { IAEA }\end{array}$ & $\begin{array}{l}\text { Wotld } \\
\text { Healih } \\
\text { Organizalion }\end{array}$ & $\begin{array}{l}\text { International } \\
\text { storage } \\
\text { dams and } \\
\text { reservoirs }\end{array}$ & $\begin{array}{l}\text { Downwardly } \\
\text { dispersed to } \\
\text { socielies }\end{array}$ & $\begin{array}{l}\text { Operators of } \\
\text { United } \\
\text { Nations } \\
\text { motor pool }\end{array}$ & $\begin{array}{l}\text { People who } \\
\text { maintain } \\
\text { internationat } \\
\text { headquatters } \\
\text { buildings }\end{array}$ \\
\hline
\end{tabular}


systems that lack a given process to use an alternative process to accomplish a similar effect. Individual bacteria cannot adapt to the environment by learning, since they lack associator and memory subsystems, but bacterial colonies do adapt by altering the expression of genes. Components of the
20 subsystems at each level of living systems are listed in table 2 .

Similar variables can be measured in each subsystem at all levels. These are such things as quantity, quality, rate, and lag in flows of matter, energy, or information.

TABLE 2 (concluded).

\begin{tabular}{|c|c|c|c|c|c|c|c|c|c|c|}
\hline $\begin{array}{l}\text { Subsystem } \\
\text { Level } \\
\end{array}$ & $\begin{array}{l}\text { Inpul } \\
\text { transducer }\end{array}$ & $\begin{array}{l}\text { Internal } \\
\text { transducer }\end{array}$ & $\begin{array}{l}\text { Channel } \\
\text { and nel }\end{array}$ & Timer & Decoder & Assaciutar & Memory & Decider & Encoder & $\begin{array}{l}\text { Oulpul } \\
\text { trallsaucer }\end{array}$ \\
\hline Cell & $\begin{array}{l}\text { Receplor siles } \\
\text { on membrane } \\
\text { for activation of } \\
\text { cyclic AMP } \\
\end{array}$ & $\begin{array}{l}\text { Repressor } \\
\text { molecules }\end{array}$ & $\begin{array}{l}\text { Pathways of } \\
\text { mANA, second } \\
\text { messengers }\end{array}$ & $\begin{array}{l}\text { Fluctuating ATP } \\
\text { and NADP }\end{array}$ & $\begin{array}{l}\text { Moleculat } \\
\text { binding sites }\end{array}$ & Unknown & Unknown & Regulator genes & $\begin{array}{l}\text { Struclure that } \\
\text { synthesizes } \\
\text { hormones }\end{array}$ & $\begin{array}{l}\text { Presynaptic } \\
\text { membrane } \\
\text { ol neuron }\end{array}$ \\
\hline Organ & $\begin{array}{l}\text { Receplor } \\
\text { cell of } \\
\text { sense } \\
\text { organ } \\
\end{array}$ & $\begin{array}{l}\text { Specialized } \\
\text { cell of sinoatrial } \\
\text { node of heart }\end{array}$ & $\begin{array}{l}\text { Nerve nel ol } \\
\text { organ }\end{array}$ & $\begin{array}{l}\text { Hearl } \\
\text { pacernaker }\end{array}$ & $\begin{array}{l}\text { Second echeion } \\
\text { cell of sense } \\
\text { organ }\end{array}$ & $\begin{array}{l}\text { None lound } \\
\text { upwardly } \\
\text { dispersed to } \\
\text { organism }\end{array}$ & $\begin{array}{l}\text { Nonte lound, } \\
\text { upwardiy } \\
\text { dispersed to } \\
\text { organism }\end{array}$ & $\begin{array}{l}\text { Sympathelic } \\
\text { liber of } \\
\text { sinoatrial node } \\
\text { ol heart }\end{array}$ & $\begin{array}{l}\text { Presynaptic } \\
\text { region ol } \\
\text { oulput } \\
\text { neuron }\end{array}$ & $\begin{array}{l}\text { Presynaplic } \\
\text { eggion of } \\
\text { oulpul } \\
\text { neuron } \\
\end{array}$ \\
\hline Organism & Sense organs & Proprioceplors & $\begin{array}{l}\text { Hormenal } \\
\text { pathways. } \\
\text { central and } \\
\text { periphesal } \\
\text { nerve nets }\end{array}$ & $\begin{array}{l}\text { Supraoptic } \\
\text { nuclei of } \\
\text { thalamus }\end{array}$ & Sensory nuclei & $\begin{array}{l}\text { Untnown } \\
\text { neural } \\
\text { companeins }\end{array}$ & $\begin{array}{l}\text { Unknown } \\
\text { meural } \\
\text { components }\end{array}$ & $\begin{array}{l}\text { Componenis at } \\
\text { several echelons } \\
\text { ol iservous } \\
\text { system }\end{array}$ & $\begin{array}{l}\text { Temporoparielal } \\
\text { ared of } \\
\text { dominant } \\
\text { hemisphere of } \\
\text { human cortex }\end{array}$ & $\begin{array}{l}\text { Larynx; olher } \\
\text { companenis } \\
\text { that output } \\
\text { signals }\end{array}$ \\
\hline Group & $\begin{array}{l}\text { Crewmember } \\
\text { who receives } \\
\text { messages irom } \\
\text { ground contiol }\end{array}$ & $\begin{array}{l}\text { Crewinember } \\
\text { who reports } \\
\text { crew's reaclions } \\
\text { to lile in capsule } \\
\end{array}$ & $\begin{array}{l}\text { Aslronauts who } \\
\text { communtcate } \\
\text { person to person }\end{array}$ & $\begin{array}{l}\text { Dispersed to } \\
\text { all members } \\
\text { who hear } \\
\text { lime siguals }\end{array}$ & $\begin{array}{l}\text { Merriber who } \\
\text { explanns coded } \\
\text { message }\end{array}$ & $\begin{array}{l}\text { Dispersed to ull } \\
\text { members who } \\
\text { leam new } \\
\text { lechniques }\end{array}$ & $\begin{array}{l}\text { Dispersed } \\
10 \text { all } \\
\text { crewmenbers }\end{array}$ & $\begin{array}{l}\text { Caplain ol crew } \\
\text { in capsule }\end{array}$ & $\begin{array}{l}\text { Members who } \\
\text { write reports } \\
\text { ot space } \\
\text { experience }\end{array}$ & $\begin{array}{l}\text { Members } \\
\text { who repoil } \\
\text { to Mission } \\
\text { Controt }\end{array}$ \\
\hline Organizalion & $\begin{array}{l}\text { NASA } \\
\text { secrelaries } \\
\text { who take } \\
\text { incoming calls }\end{array}$ & $\begin{array}{l}\text { Representalive } \\
\text { of employees } \\
\text { who reports } \\
10 \text { execulive }\end{array}$ & $\begin{array}{l}\text { Users of NASA } \\
\text { inlernal phone } \\
\text { notwork }\end{array}$ & $\begin{array}{l}\text { Ollice } \\
\text { responsible } \\
\text { lor scheduling } \\
\text { Ilights }\end{array}$ & $\begin{array}{l}\text { Experts who } \\
\text { explain specs } \\
\text { to contractors }\end{array}$ & $\begin{array}{l}\text { People who } \\
\text { t'ain new } \\
\text { employees }\end{array}$ & $\begin{array}{l}\text { Filing } \\
\text { department }\end{array}$ & $\begin{array}{l}\text { NASA } \\
\text { executives, } \\
\text { department } \\
\text { neads, middle } \\
\text { managers }\end{array}$ & $\begin{array}{l}\text { Public relations } \\
\text { slall }\end{array}$ & $\begin{array}{l}\text { Administrator } \\
\text { who inakes } \\
\text { policy } \\
\text { television } \\
\text { speech }\end{array}$ \\
\hline Community & $\begin{array}{l}\text { Operators of } \\
\text { downlink to } \\
\text { Earth }\end{array}$ & $\begin{array}{l}\text { Communicalor } \\
\text { over downlink } \\
\text { lo Earth }\end{array}$ & $\begin{array}{l}\text { Psychologisis } \\
\text { who report } \\
\text { on morale of } \\
\text { spaceferers }\end{array}$ & $\begin{array}{l}\text { Carelakers of } \\
\text { ctocks in } \\
\text { community }\end{array}$ & $\begin{array}{l}\text { Users of } \\
\text { communication } \\
\text { system in } \\
\text { space station }\end{array}$ & $\begin{array}{l}\text { Engineers } \\
\text { who interpiel } \\
\text { building } \\
\text { blueptinls }\end{array}$ & $\begin{array}{l}\text { Scientists } \\
\text { who do } \\
\text { lesedich in } \\
\text { space }\end{array}$ & $\begin{array}{l}\text { Ceniral } \\
\text { computes } \\
\text { of space } \\
\text { communty }\end{array}$ & $\begin{array}{l}\text { Cornmanding } \\
\text { ofticer and } \\
\text { stall }\end{array}$ & $\begin{array}{l}\text { Olficer who } \\
\text { witles report } \\
\text { to Earth } \\
\text { stallon }\end{array}$ \\
\hline Society & $\begin{array}{l}\text { Forelgn news } \\
\text { services }\end{array}$ & $\begin{array}{l}\text { Public opinion } \\
\text { polling } \\
\text { organizalions: } \\
\text { volers }\end{array}$ & $\begin{array}{l}\text { Telephone and } \\
\text { communications } \\
\text { organizations }\end{array}$ & $\begin{array}{l}\text { Legislaturs } \\
\text { who decide on } \\
\text { time and zone } \\
\text { changes }\end{array}$ & Cryplographers & $\begin{array}{l}\text { All teaching } \\
\text { instifutions ol a } \\
\text { country }\end{array}$ & $\begin{array}{l}\text { Keepers of } \\
\text { naltonal } \\
\text { archives }\end{array}$ & $\begin{array}{l}\text { Voters and } \\
\text { oflicials of } \\
\text { national } \\
\text { governmen } \\
\end{array}$ & $\begin{array}{l}\text { Dralters of } \\
\text { trealtes }\end{array}$ & $\begin{array}{l}\text { Nulional } \\
\text { representalives } \\
\text { to international } \\
\text { meelings }\end{array}$ \\
\hline $\begin{array}{l}\text { Supranational } \\
\text { system }\end{array}$ & $\begin{array}{l}\text { UN Assembly } \\
\text { tearing } \\
\text { speaker Irom } \\
\text { nommember } \\
\text { lerritory }\end{array}$ & $\begin{array}{l}\text { Speaker Irom } \\
\text { member } \\
\text { country to } \\
\text { supranalional } \\
\text { meeling }\end{array}$ & INTELSAT & $\begin{array}{l}\text { Personnel of } \\
\text { Greenwich } \\
\text { observatory }\end{array}$ & $\begin{array}{l}\text { Transialous for } \\
\text { supranational } \\
\text { moetings }\end{array}$ & $\begin{array}{l}\text { FAO unils that } \\
\text { teach larming } \\
\text { methods in Third } \\
\text { World nations }\end{array}$ & $\begin{array}{l}\text { Librarlans of } \\
\text { UN libraries }\end{array}$ & $\begin{array}{l}\text { National } \\
\text { represenlatives } \\
\text { to mternational } \\
\text { space } \\
\text { conferences } \\
\end{array}$ & $\begin{array}{l}\text { UN Olfice of } \\
\text { Public } \\
\text { Intormalion }\end{array}$ & $\begin{array}{l}\text { Oflicial who } \\
\text { announcess } \\
\text { decisions of } \\
\text { supranal ional } \\
\text { body }\end{array}$ \\
\hline
\end{tabular}

Nole. The components listud in table 2 are examples selected from many possible structures of each subsystem and at each level. At the organism level aimals are from human rather than animal able 2 places special emphasis on living jrus, allow systems. This choice syslems involved in space exploration and habitalion At each level the examples of subsystem components are trom different lypes and above, components involved in cammunications rather ihan monetary flows are used as examples in intormation processing subsystems. This is done because monetary flows, while obviously important, are found only in hurnan systems and are currently nol very significant in space habitations. 


\section{Adjustment Processes}

Living systems of all kinds exist in an uncertain environment to which they must adapt. Excesses or deficits of necessary matter-energy or information inputs can stress them and threaten their continued well-being or even their existence. In the midst of flux, they must maintain steady states of their innumerable variables.

Each system has a hierarchy of values that determines its preference for one internal steady state rather than another; that is, it has purposes. These are comparison values that it matches to information inputs or internal transductions to determine how far any variable has been forced from its usual steady state. A system may also have external goals, such as finding and killing prey or reaching a target in space.

All living systems have adjustment processes, sometimes called "coping mechanisms," that they can use to return variables to their usual steady states. These are alterations in the rates or other aspects of the flows of matter, energy, and information. Subsystems also match the state of each variable they control with a comparison signal and use adjustment processes to correct deviations from it. In general, more adjustment processes are available to higher level systems than to those at lower levels.

Countless small adjustments take place continually as a living system goes about its essential activities. Minor deviations can often be corrected by a single component of one subsystem. More serious threats are countered by a greater number of subsystems or all of them. Severe deviations from steady state constitute pathology that a system may not be able to correct.

The six classes of adjustment processes vary the input, internal, and output processing of matter and energy (matter-energy) and information.

All adjustment processes are used at some cost to the system. Ordinarily a system that survives chooses the least costly of its alternatives.

\section{Cross-Level Research}

Because of the similarities that exist across all levels of life, empirical cross-level comparisons are possible and are the sort of basic research that is most characteristic of living systems science. Since the evolution of the levels has occurred in physical space-time, their comparable subsystems and variables can ultimately be measured in meter-kilogram-second or compatible units. 
Research to test cross-level hypotheses began in the 1950 s and continues to the present (Miller 1986a). Such research can provide accurate and dependable fundamental knowledge about the nature of life that can be the basis for a wide range of applications.

LST research strategy: The following strategy is used to analyze systems at any level. It has been applied to systems as different as psychiatric patients and organizations.

1. Identify and make a two- or three-dimensional map of the structures that carry out the 20 critical subsystem processes in the system being studied (see table 2).

2. Identify a set of variables in each subsystem that describe its basic processes. At levels of group and below, these represent aspects of the flows of matter, energy, and information. At levels of organization and above it has proved useful to measure five instead of three flows: MATFLOW, materials; ENFLOW, energy; COMFLOW, person-toperson, person-to-machine, and machine-to-machine communications information; PERSFLOW, individual and group personnel (who are composed of matter and energy and also store and process information); and MONFLOW, money, money equivalents, account entries, prices, and costs $-a$ special class of information.

3. Determine the normal values of relevant variables of every subsystem and of the system as a whole and measure them over time, using appropriate indicators.

The normal values of innumerable variables have been established for human organisms. A physician can make use of reliable tests and measurements and accepted therapeutic procedures to discover and correct pathology in a patient. Similar information is not available to the specialist who seeks to improve the cost-effectiveness of an organization. Studies that make it possible to generalize among organizations are few, with the result that the usual values of most variables are unknown at organization and higher levels. This lack makes it difficult to determine to what extent an organization's processes deviate from "normal" for systems of its type. Pathology in an organization may become apparent only when deviation is so great that acceptance of the organization's products or services declines or bankruptcy threatens. 
4. Take action to correct dysfunctional aspects of the system and make it healthier or more cost-effective, by, for example, removing a psychiatric patient from an unfavorable environment, altering the structure or process of a work group, or introducing nonliving artifacts (like computers or faster transport equipment) into an organization.

Our proposed study would apply the above strategy to evaluating the cost-effectiveness of the operations of a crew of a space station, tracking the five categories of flows through its 20 subsystems, identifying its strengths and dysfunctions, and recommending ways to improve its operations. Later a similar approach could be applied to a mission to Mars, a lunar settlement, and perhaps other human communities in space. It could also be used at Antarctic bases.

Validation of LST: LST arises from the integration of a large number of observations and experiments on systems of a variety of types that represent all eight levels. As with other scientific theories, however, its assertions cannot be accepted without validation.

How have some of the well-known theories been validated? Consider, for example, Mendeleyev's periodic table of the elements, first published in the mid-19th century. In its original form, it was based on a hypothesis that the elements could be arranged according to their atomic weights and that their physical properties were related to their place in the table. Revisions by Mendeleyev and others over succeeding years led to discovery of errors in the assigned atomic weights of 17 elements and included new elements as they were discovered, but the properties of some required that several pairs of elements be reversed. In the early 1920 s, after the discovery of atomic numbers, a hypothesis by van den Brock that the table would be correct if atomic number rather than atomic weight were used as its basis was confirmed by H. G. J. Moseley's measurement of spectral lines. The present form of the table places all known elements in correct order and has made it possible to predict the characteristics of elements to be discovered in nuclear reactions.

Confirmation of Mendeleyev's theory required testing of a succession of hypotheses based on it. No theory can be considered valid until such observation and research have shown that its predictions about the real systems with which it is concerned are accurate.

If LST is to have validity and usefulness, confirmation of hypotheses related to it is 
essential. The first test of an LST hypothesis was a cross-level study of information input overload at five levels of living systems, carried out in the 1950s (Miller 1978, pp. 121-202). It confirmed the hypothesis that comparable information input-output curves and adjustment processes to an increase in rate of information input would occur in systems at the level of cell, organ, organism, group, and organization. Numerous other quantitative experiments have been done on systems at various levels to test and confirm crosslevel hypotheses based on living systems theory (e.g., Rapoport and Horvath 1961, Lewis 1981). Such tests support the validity of living systems theory.

\section{Applications of Living Systems Theory}

Living systems theory has been applied to physical and mental diagnostic examinations of individual patients and groups (Kluger 1969, Bolman 1970, Kolouch 1970) and to psychotherapy of individual patients and groups (Miller and Miller 1983). An early application of LST at organism, group, and organization levels was a study by Hearn in the social service field (1958).
An application of living systems concepts to families described the structure, processes, and pathologies of each subsystem as well as feedbacks and other adjustment processes (Miller and Miller 1980). A subsystem review of a real family* was carried out in a videotaped interview that followed a schedule designed to discover what members were included in each of several subsystems, how the family decided who would carry out each process, how much time was spent in each, and what problems the family perceived in each process.

Research at the level of organizations includes a study of some large industrial corporations (Duncan 1972); general analyses of organizations (Lichtman and Hunt 1971, Reese 1972, Noell 1974, Alderfer 1976, Berrien 1976, Rogers and Rogers 1976, and Merker 1982, 1985); an explanation of certain pathologies in organizations (Cummings and DeCotiis 1973); and studies of accounting (Swanson and Miller 1989), management accounting (Weekes 1983), and marketing (Reidenbach and Oliva 1981). Other studies deal with assessment of the effectiveness of a hospital (Merker 1987) and of a metropolitan transportation utility (Bryant 1987).

"Personal communication (videotape and script) from R. A. Bell, 1986. 
The largest application of LST has been a study of the performance of 41 U.S. Army battalions (Ruscoe et al. 1985). It revealed important relationships between characteristics of matter-energy and information processing and battalion effectiveness.

A research study is being conducted in cooperation with IBM, applying living systems process analysis to the flows of materials, energy, communications, money, and personnel in a corporation, in order to determine its costeffectiveness and productivity. Discussions of possible use of living systems process analysis to evaluate cost-effectiveness in Government agencies are under way with the General Accounting Office of the United States.

Several researchers (Bolman 1967; Baker and O'Brien 1971; Newbrough 1972; Pierce 1972; Burgess, Nelson, and Wallhaus 1974) have used LST as a framework for modeling, analysis, and evaluation of community mental health activities and health delivery systems. LST has also provided a theoretical basis for assessing program effectiveness in community life (Weiss and Rein 1970).

After a pretest of comparable methods of evaluation, a study of public schools in the San Francisco area was carried out (Banathy and Mills 1985). A more extensive study of schools in that area is now in process under a grant from the National Science Foundation.

The International Joint Commission of Canada and the United States has been using living systems theory as a conceptual framework for exploring the creation of a supranational electronic network to monitor the region surrounding the border separating those two countries (Miller 1986b).

Other applied research studies are in planning stages, and proposals are being prepared for some of them. These include an investigation of how to combine bibliographical information on living systems at the cell, organ, and organism levels by the use of computer software employing living systems concepts; an analysis of insect behavior in an ant nest; and a study of organizational behavior and organizational pathology in hospitals.

The conceptual framework of LST and its implications for the generalization of knowledge from one discipline to another have been discussed by many authors (see Miller 1978 and Social Science Citation Index 1979 ff.). 
It is too early to make a definitive evaluation of the validity of living systems theory. Not enough studies have been carried out and not enough data have been collected. It is possible to say, however, that the theory has proved useful in conceptualizing and working with real systems at seven of the eight levels. Studies at the eighth level, the organ, have not so far been carried out but these will be undertaken in the future. In addition, the general consensus of published articles about the theory has been supportive.

\section{A Proposed LST Space Research Project}

It appears probable that the space station that is now in the planning stage at NASA will become a reality in the next few years. It would be a prototype for future nonterrestrial communities - on the Moon and on Mars.

The crew of such a station would include not only astronauts but also technicians and other personnel. They would spend a much longer time in the space environment than crews of space vehicles on previous missions had spent.

Our research method would use LST process analysis to study the space station crew, identify its strengths and dysfunctions, evaluate the performance of personnel, and recommend ways to improve the cost-effectiveness of its operations.

Until the space station is in operation, we would study human activities on modules of a simulated space station. The method used in this phase could later be applied to the space station and eventually to settlements on the Moon or on Mars.

The basic strategy of LST process analysis of organizations is to track the five flows-matter, energy, personnel, communication, and monetary information - through the 20 subsystems and observe and measure variables related to each. Since money flows would probably be unimportant in the early stages of a space station, only the first four are relevant to the first phase of this research. A larger and more permanent space settlement might well have a money economy.

We would measure such variables as rate of flow of essential materials; lags, error rates, and distortion in information transmissions; timeliness of completing assigned tasks; and time and resource costs of various activities.

\section{Data Collection}

We plan to collect both subjective and objective data. 
Subjective data would consist of responses by personnel to questions about their activities related to the variables under study. Questions would be presented and answered on computer terminals. Responses would be collected in a centralized knowledge base for analysis by a computerized expert system.

In addition to these subjective reports, our research design includes the use of objective indicators or sensors to monitor flows in all subsystems and components and measure them on a real-time basis. A time series of data about them would be transmitted or telemetered to the knowledge base in the computer.

In addition to standard measures of units of energy, quantities of material, bits of information, and the usual personnel records, we plan to make use of a novel technical innovation to monitor the movements of personnel and materials. It consists of badges similar to the ordinary ID badges worn by personnel in many organizations. Each badge contains an infrared transponder in the form of a microchip that, on receipt of an infrared signal from another transponder on the wall, transmits a stream of 14 characters that identifies the person or object to which the badge is attached. With this equipment it is possible to locate in $0.7 \mathrm{sec}$ any one of up to 65000 persons or materials such as equipment, furniture, weapons, ammunition, or food. If desired, the phone nearest to a person's present location can be rung in another $0.3 \mathrm{sec}$.

In this way many aspects of processes such as the response time of personnel to questions or commands, the average time spent in various activities, the patterns of interactions among people, and the movement of equipment to different parts of the space station can be measured without unduly disrupting the day-to-day activities of the system.

All the data on the five major flows from questionnaires and objective indicators would be stored in a single computer. Such data could help NASA officials evaluate the effects on space station operations of changes in policy or procedure. In addition, measurements of variables over time make it possible to determine norms for them and to identify deviations that may show either special strengths or dysfunctions. With such information, a computerized expert system can analyze the relationships among the different variables of the five major flows and suggest ways to improve the space station's effectiveness. 
Figure 3 is a diagram of the space station showing how the five flows, MATFLOW, ENFLOW, COMFLOW, PERSFLOW, and MONFLOW, might go through its subsystems. The subsystems are identified by the symbols shown in figure 2.

Even when only the primary flows of each sort in the space station are superimposed in a diagram like figure 3 , they form a very complex pattern.

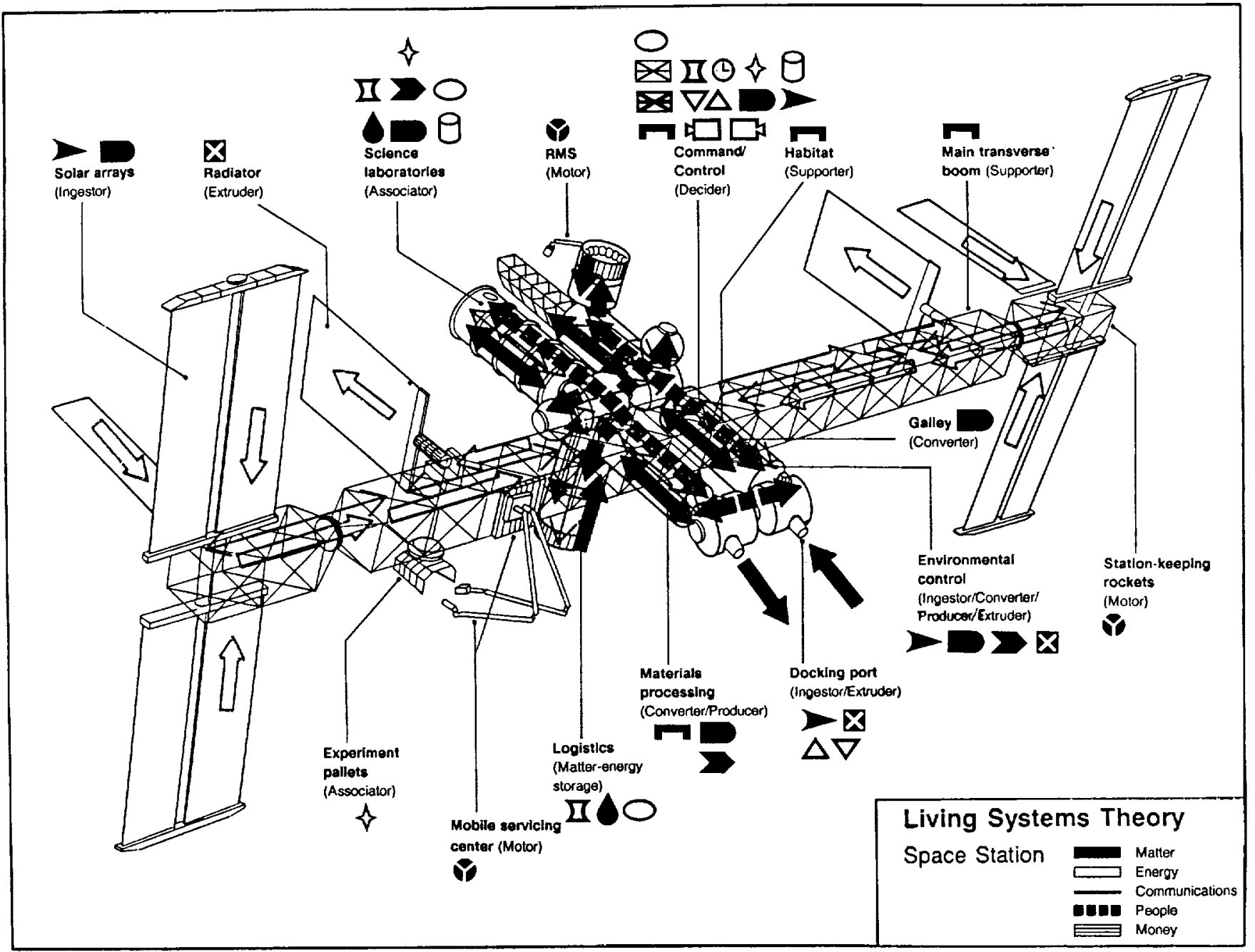

Figure 3

The Five Flows in the Subsystems of the Space Station 
In a real space situation, use of monitoring would be of value in many ways. It could identify and report technological or human problems as they occurred. Badges would make it easy for each spacefarer to be found at all times. The officer of the watch would be able to see instantly on a screen the location of all crewmembers with active badges. In addition, the computer could be programmed to present possible solutions to problems and even to initiate necessary steps to assure continuation of mission safety and effectiveness in the event of inflight emergencies or breakdowns.
Analyzing such flows in subsystems of the space station would provide experience with a novel system for monitoring both living and nonliving components of future space habitations. This experience could well lead to use of similar methods on manned missions to the Moon or to Mars.

For instance, some time in the next century such procedures could be applied to a lunar outpost, a community that would include men, women, and children. A wide range of professional interests, expertise, abilities, and perhaps cultures might be represented in

\section{Monitoring the Movement of People} and Equipment at a Space Base

identification badges containing tiny transponders could track the movements of the woman playing tennis in this space base or the man running on the track. Similarly, property tags with such microchips could report the up-to-thesecond location of the monorail train and guard the artwork and plants against theft. Communication of the microchip transponders with transponders mounted on walls would continually report the movements of both personnel and materials to a computerized expert system. If the man servicing the monorail train on the lower level were to get hurt, such automatic monitoring could summon aid in 1 second. And analysis by living systems theory methods could determine whether the interaction between the two men on the walkway is an insignificant waste of time, an important social encounter, or a vital part of an informal communications network.

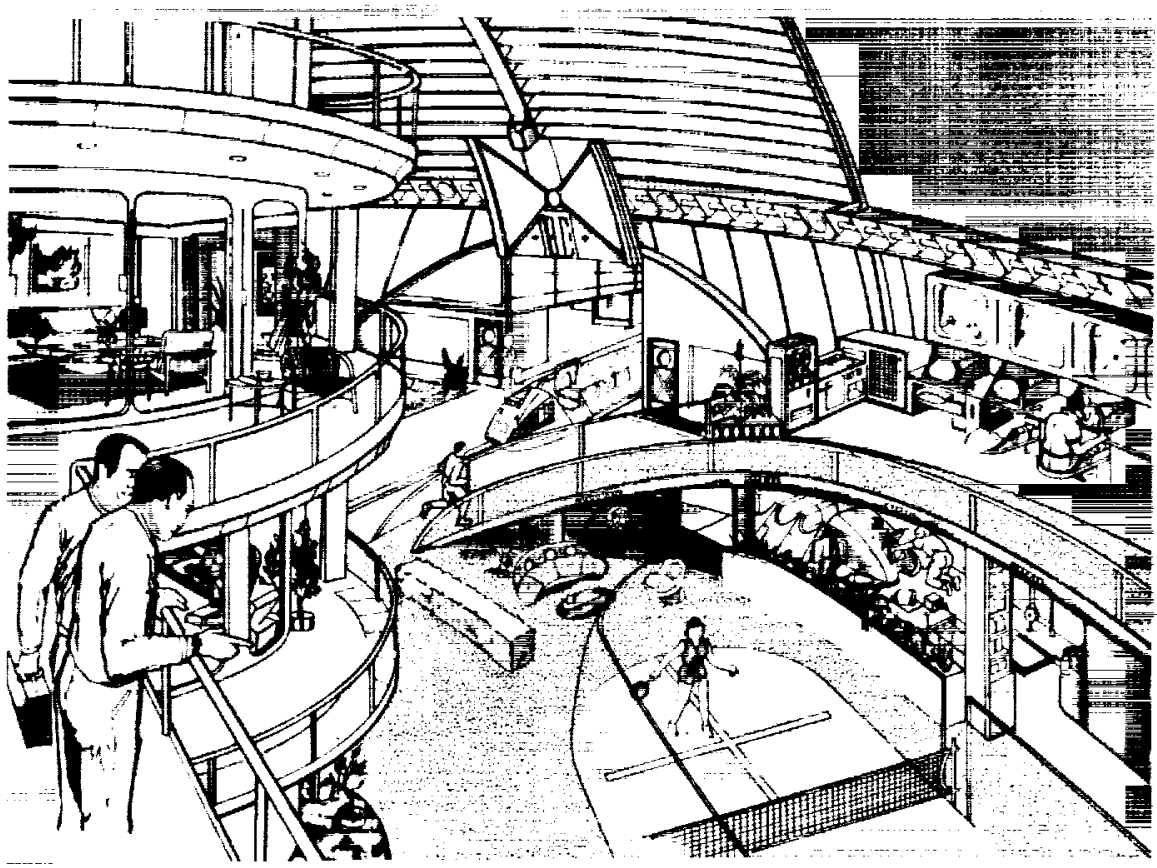


the lunar community. Residents would live for long times under at least 6 feet of earth or other shielding, which would provide protection from solar radiation, solar flares, and other lunar hazards.
Figure 4 shows such a lunar outpost with designated areas for a command center, habitation, solar power collection, a small nuclear power plant, lunar mines, a solar furnace to use the direct rays of
Figure 4

The Five Flows in the Subsystems of a Lunar Outpost

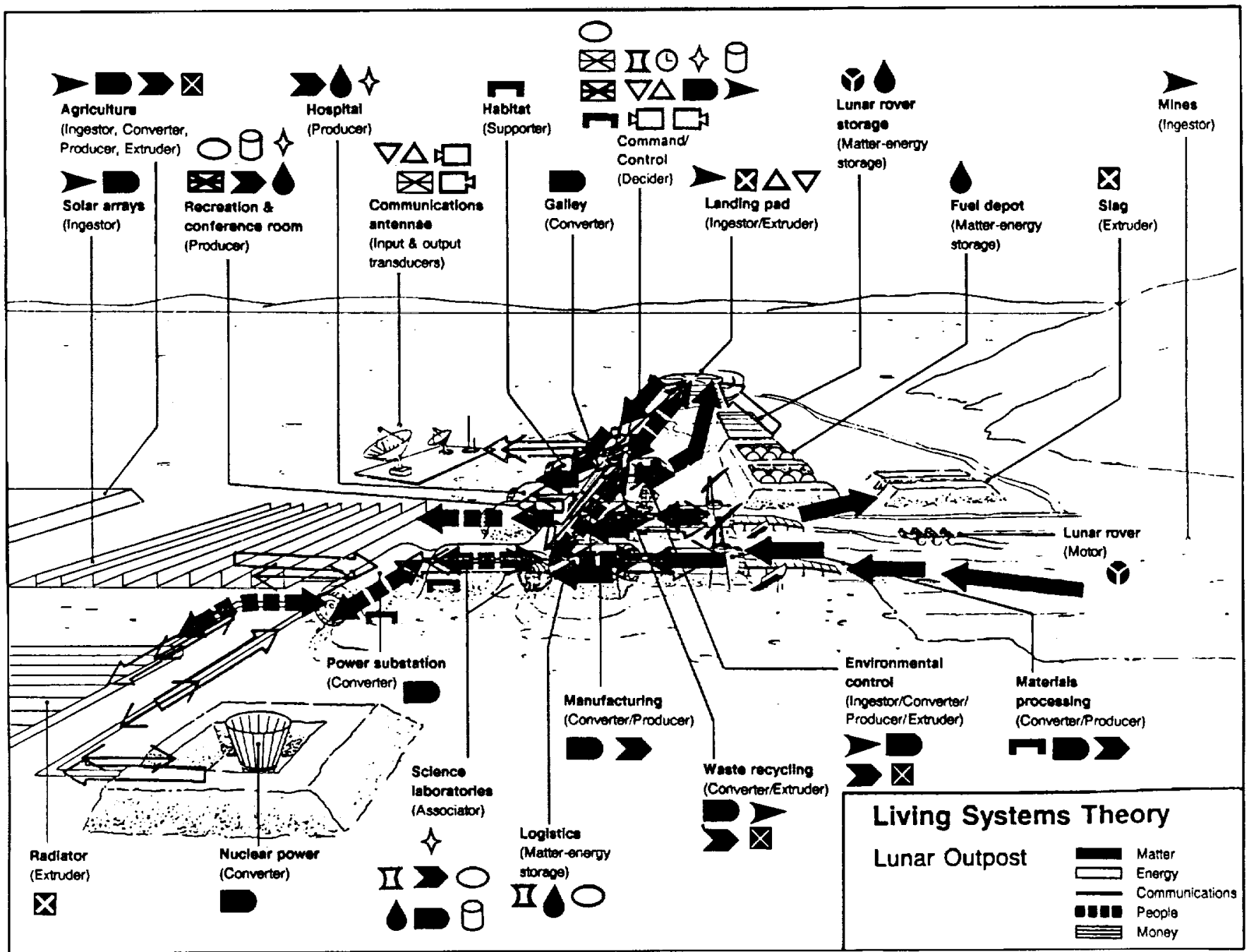


the Sun for smelting ore and heating the station, a factory, a slag heap, a farm, recycling oxygen and hydrogen, waste disposal, and lunar rovers to transport materials and people on the surface of the Moon from one part of the community to others, as well as for travel outside the immediate area. The five flows through the 20 subsystems of this community are diagramed as were those of the space station shown in figure 3.

\section{Conclusion}

The conceptual system and methology of living systems theory appear to be of value to research on life in isolated environments. A space station, which must provide suitable conditions for human life in a stressful environment that meets none of the basic needs of life, is an extreme example of such isolation.

A space station would include living systems at levels of individual human beings, groups of people engaged in a variety of activities, and the entire crew as an organization. It could also carry living systems of other species, such as other animals and plants. Using the subsystem analysis of living systems theory, planners of a station, either in space or on a celestial body, would make sure that all the requirements for survival at all these levels had been considered. Attention would be given not only to the necessary matter and energy (including artifacts such as machinery and implements) but also the equally essential information flows that integrate and control living systems. Many variables for each subsystem could be monitored and kept in steady states.

Use of living systems process analysis of the five flows of matterenergy and information would assure that all members of the crew received what they needed, that distribution and communication were timely and efficient, and that the command centers within the station and on Earth were fully informed of the location and activities of personnel, particularly during an emergency.

\section{References}

Alderfer, C. P. 1976. Change Processes in Organizations. In Handbook of Industrial and Organizational Psychology, ed. M. D. Dunnette, 1592-1594. Chicago: Rand-McNally.

Baker, F., and G. O'Brien. 1971. Intersystem Relations and Coordination of Human Service Organizations. American Journal of Public Health 61:130-137. 
Banathy, B. S., and S. R. Mills. 1985. The Application of Living Systems Process Analysis in Education. ISI Monograph 85-7.

Berrien, F. K. 1976. A General Systems Approach to Organizations. In Handbook of Industrial and Organizational Psychology, ed. M. D. Dunnette, 42-43. Chicago: Rand McNally.

Bolman, W. M. 1967. Theoretical and Community Bases of Community Mental Health. American Journal of Psychiatry 124: 7-21.

1970. Systems Theory, Psychiatry, and School Phobia. American Journal of Psychiatry 127: 65-72.

Bryant, D. D. 1987. A Living Systems Process Analysis of a Public Transit System. Behavioral Science 32:293-303.

Burgess, J.; R. H. Nelson; and R. Wallhaus. 1974. Network Analysis as a Method for the Evaluation of Service Delivery Systems. Community Mental Health Journal 10 (3): 337-345.

Connors, M. M.; A. A. Harrison; and F. R. Akins. 1985. Living Aloft: Human Requirements for Extended Spaceflight. NASA SP-483.
Cummings, L. L., and T. A. DeCotiis. 1973. Organizational Correlates of Perceived Stress in a Professional Organization. Public Personnel Management 2:277.

Duncan, D. M. 1972. James G. Miller's Living Systems Theory: Issues for Management Thought and Practice. Academic Management Journal 15:513-523.

Hearn, G. 1958. Theory Building in Social Work. Toronto: Univ. of Toronto Press.

Kluger, J. M. 1969. Childhood Asthma and the Social Milieu. Journal of the American Academy of Child Psychiatry 8:353-366.

Kolouch, F. T. 1970. Hypnosis in Living Systems Theory: A Living Systems Autopsy in a Polysurgical, Polymedical, Polypsychiatric Patient Addicted to Talwin. American Journal of Clinical Hypnosis 13 (1): 22-34.

Lewis, L. F., II. 1981. Conflicting Commands versus Decision Time: A Cross-Level Experiment. Behavioral Science 26:79-84.

Lichtman, C. M., and R. G. Hunt. 1971. Personality and Organization Theory: A Review of Some Conceptual Literature.

Psychological Bulletin 75: 285-287. 
Lockheed Missiles and Space

Company. 1985. Issues. Vol. 4

of Final Report, Space Station

Human Productivity Study, xi-xiv.

Sunnyvale, CA: Lockheed

Missiles and Space Company, Inc.

Merker, S. L. 1982. Living

Systems as a Management Tool.

Proc. 26th Ann. Mtg. Soc. General

Systems Research, 886-888.

1985. Living Systems

Theory: A Framework for Management. Behavioral Science 30:187-194.

1987. Living Systems

Process Analysis of an Urban Hospital. Behavioral Science 32: 304-314.

Miller, J. G. 1955. Toward a General Theory for the Behavioral Sciences. American

Psychologist 10: 513-531.

1965. Living Systems:

Basic Concepts; Living Systems:

Structure and Process. Behavioral Science 10:193-237; 237-379.

1978. Living Systems.

New York: McGraw-Hill. 1986a. Can Systems

Theory Generate Testable Hypotheses? From Talcott Parsons to Living Systems Theory. Systems Research 3:

73-84.

1986b. A Living

Systems Analysis of a Canada/

U.S. Boundary Region. In Toward

a Transboundary Monitoring

Network: A Continuing Binational

Exploration, ed. P. T. Haug, G. L. Bandurski, and A. L. Hamilton, vol. I, pp. 132-144. Washington, DC: U.S. State Dept., Int. Joint Commission U.S.A. and Canada.

Miller, J. G., and J. L. Miller. 1980. The Family as a System. In The Family: Evaluation and Treatment, ed. C. K. Hofling and J. M. Lewis, 141-184. New York: Brunner/Mazel.

1983. General Living

Systems Theory and Small

Groups. In Comprehensive Group Psychotherapy, ed. H. I. Kaplan and B. J. Sadock, 33-47.

Baltimore: Williams \& Wilkins.

Miller, J. L. 1990. The Timer. Behavioral Science 35:164-196. 
National Commission on Space. 1986. Pioneering the Space Frontier. New York: Bantam Books.

Newbrough, J. R. 1972. Community Psychology. American Psychologist 27:770.

Noell, J. J. 1974. On the Administrative Sector of Social Systems: An Analysis of the Size and Complexity of Government Bureaucracies in the American States. Social Forces 52:549-559.

Pierce, L. M. 1972. Usefulness of a Systems Approach for Problem Conceptualization and Investigation. Nursing Research 21:509-517.

Rapoport, A., and W. J. Horvath. 1961. A Study of a Large Sociogram. Behavioral Science 6: 279-291.

Reөse, W. G. 1972. An Essay on Administration. American Journal of Psychiatry 128:69-72.

Reidenbach, R., and T. A. Oliva. 1981. A Framework for Analysis. Journal of Marketing 45 (4-Fall): 42-52.
Rogers, E. M., and R. A. Rogers. 1976. Communication in Organizations, pp. 29-58. New York: Free Press.

Ruscoe, G. C., et al. 1985. The Application of Living Systems Theory to 41 U.S. Army Battalions. Behavioral Science 30:1-56.

Social Science Citation Index. $1979 \mathrm{ff}$.

Swanson, G. A., and J. G. Miller. 1989. Measurement and Interpretation in Accounting. New York: Quorum Books.

Weekes, W. H. 1983. A General Systems Approach to Management Accounting. Salinas, CA: Intersystems Publications.

Weiss, R. S., and M. Rein. 1970. The Evaluation of Broad-Aim Programs: Experimental Design, Its Difficulties, and an Alternative. Administrative Science Quarterly 15 (1): 97-109. 